\title{
Suomalaisten energiatiedon lukutaito: tutkimuksen toteutuksen kuvaus
}

\author{
Teija Keränen \\ Oulun yliopisto \\ teija.keranen@oulu.fi
}

Asiasanat: informaatiolukutaito; energia; väestötutkimus; kyselytutkimus

Ilmastotavoitteiden saavuttaminen vuoteen 2030 mennessä on haaste suomalaisille. Se edellyttää energiatiedon hyödyntämistä, jotta uusiutuvien energiamuotojen tarjontaa ja käyttöä voidaan lisätä. Energiatietoa ei kuitenkaan ole helppoa ymmärtää. Energiajärjestelmä on kompleksinen ja energiaterminologia vaikeaselkoista. Lisäksi kyseessä on poliittisesti kriittinen aihepiiri. Tutkimukseni lisää ymmärrystä ihmisten energiatiedon lukutaidosta. Esitän käsitteelle uuden määritelmän ja tähän perustuvan seulontavälineen. Sen avulla saatua tietoa voidaan hyödyntää energia-asioista viestittäessä sekä ihmisten kouluttamisessa energiaan liittyvissä arjen valinnoissa.

Informaatiolukutaidon tutkimus arkielämän konteksissa on toistaiseksi ollut vähäistä (Martzoukou \& Sayyad Abdi, 2017) eikä arkielämän energiatiedon lukutaitoa ole aikaisemmin tutkittu. Amerikkalaisen kirjastoseuran (American Library Association, ALA) informaatiolukutaidon määritelmä vuodelta 1989 on kyseenalaistettu ja laajempia määritelmiä esitetty.

Tutkimukseni tavoitteena on selvittää ihmisten arkielämän energiatiedon lukutaitoa eli energiatietoon liittyviä taitoja ja ymmärrystä sekä energiatiedon soveltamista arjen valinnoissa. Tutkimusasetelma on vertaileva. Kyselytutkimuksessa verrataan ilmastotyön edelläkävijäkunta Iin asukkaiden ja muiden suomalaisten energiatiedon lukutaitoa. 


\section{Tutkimuksen teoreettinen tausta}

Tutkimuksessani energiatiedon lukutaidon teoreettinen jäsentäminen määräytyy sosiokulttuurisesta näkökulmasta informaatiotutkimuksessa. Sen lähikäsitettä energialukutaito on tarkasteltu useilla tieteenaloilla. Se viittaa ihmisten kykyyn ymmärtää energiatietoon liittyviä asioita, ja siinä on erotettavissa useita tasoja, useimmin tiedollinen, tunneperäinen ja käyttäytymisen taso (DeWaters \& Powers, 2011). Vaikka määritelmä on laaja, se ei pureudu riittävästi ihmisten tietokäyttäytymiseen. Pro gradu -tutkielmassani määrittelin energiatiedon lukutaidon soveltaen terveystiedon lukutaidon määritelmää (ks. Keränen, Hirvonen, \& Huotari, 2018). Empiirisessä kyselytutkimuksessa tutkin opiskelijoiden energiatiedon lukutaitoa soveltamalla arkielämän terveystiedon lukutaidon seulontavälinettä (Everyday Health Information Literacy screening tool, Niemelä, Ek, Eriksson-Backa, \& Huotari, 2012). Väitöskirjassani laajennan energiatiedon lukutaidon määritelmää kattamaan informaatiokäyttäytymisen lisäksi tunneperäisiä ja muita käyttäytymiseen liittyviä tekijöitä, jotka soveltaessani terveystiedon lukutaidon määritelmää jäivät vähemmälle huomiolle.

\section{Menetelmä ja aineisto}

Tutkimusmenetelmänä on postikysely Iin kunnan asukkaille $(n=700)$ ja laaja väestöpohjainen postikysely suomalaisille $(n=2000)$. Kysely perustuu osittain vastaajan itsearviointiin (5-portainen Likertin asteikko), jossa kartoitetaan vastaajan omaa arviota hänen kyvystään suorittaa tietty tehtävä (nk. self-efficacy). Tämän arvion on todettu olevan yhteydessä yksilön käyttäytymiseen. Kormosin ja Giffordin (2014) mukaan käyttäytymisen muutoksen edistämisessä itsearviointityökalujen validointi on tärkeää, kuten myös objektiivisten mittareiden sisällyttäminen ympäristöystävällisen käyttäytymisen tutkimuksiin. Kyselyn lähtökohtana on Oulun yliopistossa kehitetty terveystiedon lukutaidon seulontaväline, joka on sovellettu energiakontekstiin ja täydennetty asenneja käyttäytymisväittämillä. Kysely sisältää lisäksi avoimia kysymyksiä esimerkiksi energiaan liittyvistä tiedontarpeista sekä energiatehokkuuden lisäämisen haasteista vastaajan omassa arjessa. Uusi elementti kyselyssä ovat objektiiviset mittarit vastaajan tietämykseen kohdistuvien kysymysten muodossa. Mukana on myös käyttäytymisväittämiä sekä kiinnostusta muun muassa sähköauton tai aurinkopaneeleiden hankintaan kartoitetaan. Kyselyaineisto analysoidaan tilastollisesti (esim. ristiintaulukointi, eksploratiivinen faktorianalyysi, faktorikeskiarvojen vertailu ja parametriset testit) ja sisällöllisesti teemoitellen. 


\section{Odotetut tutkimustulokset}

Tulokset osoittavat, näkyykö hiilineutraaliuteen pyrkimisen edelläkävijyys Iin kunnan asukkaiden energiatiedon lukutaidossa verrattuna muihin suomalaisiin. Uutta tietoa saadaan energiatiedon lukutaidosta esimerkiksi vastaajien sosiodemografisten tekijöiden sekä kotitalouksien ominaispiirteiden mukaan.

\section{Diskussio ja yhteenveto}

Tutkimukseni lisää ymmärrystä ihmisten energiatiedon lukutaidosta. Määrittelen käsitettä ja kehitän tähän määritelmään perustuvaa seulontavälinettä. Sen avulla saatua tietoa voidaan hyödyntää kansalaisten tukemisessa pyrkimyksissään kohti kestävää elämäntapaa. Jatkotutkimusehdotuksena esitän energiatiedon ja viestinnän vaikuttavuuden tutkimista ja vuorovaikutuksen merkitystä yhdensuuntaisen viestinnän ohella.

\section{Lähteet}

DeWaters, J. E., \& Powers, S. E. (2011). Energy literacy of secondary students in New York State (USA): A measure of knowledge, affect, and behavior. Energy Policy, 39(3), 1699-1710. https: //doi.org/10.1016/j.enpol.2010.12.049

Keränen, T., Hirvonen, N., \& Huotari, M.-L. (2018). Examining Energy Information Literacy with an Adaptation of the Everyday Health Information Literacy Screening Tool. Teoksessa S. Kurbanoğlu, J. Boustany, S. Špiranec, E. Grassian, D. Mizrachi, \& L. Roy (toim.), ECIL 2017: Information Literacy in the Workplace (ss. 470-480). Springer International Publishing.

Kormos, C., \& Gifford, R. (2014). The validity of self-report measures of proenvironmental behavior: A meta-analytic review. Journal of Environmental Psychology, 40, 359-371. https: //doi.org/10.1016/j.jenvp.2014.09.003

Martzoukou, K., \& Sayyad Abdi, E. (2017). Towards an everyday life information literacy mindset: a review of literature. Journal of Documentation, 73(4), 634-665. https://doi.org/10. 1108/JD-07-2016-0094

Niemelä, R., Ek, S., Eriksson-Backa, K., \& Huotari, M.-L. (2012). A Screening Tool for Assessing Everyday Health Information Literacy. Libri, 62(2), 125-134. https://doi.org/10.1515/ libri-2012-0009 